\title{
HÍREK
}

\section{BESZÁMOLÓ AZ ÓKORTUDOMÁNYI TÁRSASÁG 1999/2000. ÉVI TEVÉKENYSÉGÉRŐL}

Az Ókortudományi Társaság fennállásának negyvenkettedik évében is folytatta megszokott tevékenységét, ezenkívül Társaságunk tagjai három konferencián is tevékenyen szerepet vállaltak.

1. A korábbi gyakorlatnak megfelelően Társaságunk tevékenységének középpontjában a budapesti felolvasóülések álltak. A legutóbbi közgyúlés óta tizenhárom alkalommal tartottunk felolvasóülést, ebből nyolc rendes, öt pedig rendkívüli volt. Rendes üléseinken a következő előadások hangzottak el:

1999. szeptember 24-én: Nagy Árpád: A gyógyító Phoenix. A császárkori varázsgemmák néhány kérdéséről; Hubai Péter: Simon mágus — keresztény, eretnek, gnosztikus?

1999. október 22-én: Déri Balázs: A psalmos a kopt nagyheti liturgiában.

1999. november 19-én: Jean-Paul Thuillier: Les jeux étrusques: la Tombe des Olympiades; Ritoók Zsigmond: Damón.

2000. január 21-én: Kákosy László: Az egyiptomi mágikus gyógyító szobrok; Hegyi W. György: Gazdaság, politika - Gazdaságpolitika az archaikus kori görög világban.

2000. február 18-án: Gloviczky Zoltán: Naso poeta; Simon Zoltán: Keserú aranykor. Calpurnius Siculus eklogái.

2000. március 17-én: Borhy László: Aether, ardor coeli ultimus, altissimus, omnia cingens, coercens, complexus. Gondolatok a Szőny-Vásártéri menyezetfreskó ikonográfiai értelmezéséhez; Harsányi Eszter, Kurovszky Zsófia: Ókori geometriai szerkesztések nyomai a Szőny-Vásártéri mennyezetfreskón. 2000. április 21-én: Philippe Fleury (Université de Caen): Roma Antiqua; Török László: A rendezett kozmosz képe az ókori Nubiában.

2000. május 26-án: Havas László: A „saecularis” eszme mint irodalomformáló tényezó Rómában. Az öt rendkívüli a következó volt:

1999. szeptember 27-én (az Ókortudományi Társaság és az ELTE Görög Tanszékének közös szervezésében): Glenn W. Most (Heidelberg és Chicago): Anger and Pity in the Iliad.

2000. február 25-én (a Filozófiai Társasággal közös szervezésben) Komlósi Csaba:: Istentelen görögök, a görög filozófia mítoszkritikája; Vattamány Gyula: Verus Israel. Az óegyház antijudaizmusáról.

2000. április 5-én: Gisela Striker (Cambridge): The Scepticism as a kind of scepticism.

2000. április 14-én (az Indoeurópai Nyelvtudományi Tanszékkel közös szervezésben): Harunaga Isaacson (Oxford): Glimpses of some debates on the nature of liberation (mokşa) in classical Indian philosophy.

2000. április 14-én: Lorenzo Perrone (Pisa): Origen's Exegesis as a System: A Comparison between the Commentary on John and the Commentary on Matthew.

Társaságunk életében fontos a két vidéki, a Debreceni és a Szegedi Szakosztály munkája. A Debreceni Szakosztály szervezésében a következő előadások hangzottak el:

1999. szeptember 29-én: Köves-Zulauf Tamás: A hős végrendelete; Szúcs Gábor: Cicero De re publicájának történelemszemlélete; Szúcs Tamás: A modalitás kifejezése az indoeurópai alapnyelvben. 
1999. november 16-án: Hegyi W. György: Az erkölcsök romlása. Egy történeti közhely Rómában.

2000. május 3-án: Havas László: Romulus Arpinas.

A Szegedi Szakosztályban a következő előadások hangzottak el:

1999 október 2-án: Köves Zulauf Tamás: Apollo jelentősége az Aeneisben.

2000 február 29-én: Kurt Smolak: Die elegische Komödie des lateinischen Mittelalters.

2000. március 26: Christine Ratkowitsch: Mathematicus — eine lateinische Tragödie im Mittelalter.

2. A fenti felolvasóüléseken kívül három fontos konferenciája is volt a magyar ókortudománynak. Közülük az első kettő nemzetközi részvétellel zajlott le, a harmadik pedig a magyar ókortudomány seregszemléjeként értékelhető.

Időrendben első a VI. holland-magyar konferencia az apokrif irodalomról „Conference on the Apocalypse of Peter" címen, amelyet Budapesten tartottunk 1999 november 12-13-án. Ezen a következô előadások hangzottak el:

Monika Pesthy: The Apocalypse of Peter and the Pseudoclementines.

Ton Hilhorst: A Comparison between the Greek and the Etiopic Version of the Apocalypse of Peter.

Eibert Tigchelaar: The Provenance of the Apocalypse of Peter (Greek, Ethiopic?)

Jan Bremmer: The Apocalypse of Peter: Greek or Jewish?

Jacques van Ruiten: Old Testament Quotations in the Apocalypse of Peter.

Tamás Adamik: Description of Paradise in the Apocalypse of Peter.

Gerard Luttikhuisen: The Coptic-Gnostic Apocalypse of Peter: Redemption by Teaching.

Balázs Déri: On the Beauty of the Glorified Body.

István Czachesz: The Grotesque Body in the Apocalypse of Peter.

János Bolyki: False Prophets in the Apocalypse of Peter.

Lautaro Roig Lanzillotta: Eleos, nemesis or epichairekakia.

Imre Peres: Greek Sepulchral Motifs in the Apocalypse of Peter.

Attila Jakab:The Reception of the Apocalypse of Peter.

A Kapitánffy István tiszteletére rendezett konferencián 1999 november 26-án és 27-én az alábbi elôadásokat tartották:

W. Pötscher: Tritonia und Tritogeneia.

J. M. Bremer: Ridendo dicere verum.

I. Tar: Ironie und Phantastisches in der menippeischen Satire.

Harmatta J.: A türk kagán levele Maurikios császárhoz.

F. Heberlein: Nominativus cum infinitivo und Modalverb in Latein.

A. Mohay: Bemerkungen zur Verbalstammbildung im nachklassichen Griechisch.

J. Bollók: Tragefactus.

Á. Szabó: Die Geschichte und Wissenschaftsgeschichte im Altertum.

Zs. Ritoók: Ein Kampf um das Griechische.

G. Bolonyai: The Uses of Progymnasmata: The Case of „Refutation”.

L. Horváth: Polypragmosyné — negotiositas, eine vergessene Übersetzung des Janus Pannonius. Németh $G y$.: Metoikosok Athénban.

Adamik B.: A latin nyelv hivatalos használatának története.

Déri B.: Ovidius-distichon egy Árpád-kori krónikában.

Ferenczi A.: Nőgyúlölő irat a 13. századból.

V. Vavřnek: Die Wüstenväter in der spätantiken Gesellschaft.

Z. Farkas: The Chronology of Eusebius' Martyrs of Palestine.

I. Perczel: What spiritual tradition Saint Symeon, the New Theologian (949-1022) belonged to?

L. Havas: Florus bei Malalas.

T. Olajos: Le Lexique „Souda” sur le khan bulgare Kroum et les Avars.

T. Adamik: Theodulfs Palmsonntagshymnus. 
M. Pesthy: Das Perlenlied und Origenes.

Szepessy T: Petronius mai szemmel.

I. Risto: Szent István hadjárata Makedóniában a 11. században.

Szovák K.: Retorikai elmélet és politikai gyakorlat az Árpád-kor végi Magyarországon.

M. Maróth: Ein unbekanntes literarisches Werk aus der Spätantike.

Kádár Z.: Angelus Bonus.

Fehér B.: Bizánci kézmúvesség arab szemmel.

Kovács P.: Optatius Porfyrius és Pannonia.

Tegyey I.: LSJ (In memoriam Stephani Kapitánffy, lexicographi optimi).

A IV. Magyar Ókortudományi Konferenciát a Pécsi Tudományegyetem Klasszika-filológiai Tanszéke rendezte 2000. május 19-21-e között. A plenáris ülés után, amelyen Cornelia Isler-Kerényi: Dionüszoszi boldogság: Exékiasz „szemes külix”-ének egy lehetséges értelmezése címen tartott előadást, a további ülések három szekcióban párhuzamosan zajlottak.

Az I. szekcióban (filozófia) a következő elóadásokat hallhatta a közönség:

Betegh Gábor: Empedoklész és Orpheusz.

Joó Mária: A philia fogalma Platón Lüsziszében.

Heidl György: A legrendezettebb Adomány.

Vilmos László: Politika és filozófia a görög világban.

Lautner Péter: Attikosz Porphüriosz és Iamblikhosz a Timaiosz 36b-ról.

Bugár István: Dynamis: filozófiai-teológiai terminus történetéhez.

Farkas Zoltán: Eusebios és a görög filozófia.

Bárány István: Platón és Prótagorasz.

Mogyoródi Emese: Xenophanész szkepszise és a philo-szophia születése.

Gerébi György: Jakab prótoevangéliuma.

Kendeffy Gábor: Lactantius és a hellenisztikus szenvedélyelméletek.

Gelenczey-Mihálcz Alirán: A győzedelmes argumentum.

Szekeres Csilla: Filozófiai problémák Cicero De finibus bonorum et malorum c. múvében.

Dér Katalin: Abrosius Lukács-kommentárjának Prologusáról.

Somos Róbert: Egy Arisztotelész-allúzió Órigenész János evangélium-kommentárjában.

A második szekcióban (színház) az alábbi előadások hangzottak el:

Simon Attila: Aiszkhülosz: Perzsák.

Horváth Judit: Heten Thébai ellen.

Karsai György: A leláncolt Prométheusz szerkezete.

Ritoók Zsigmond: A hallgatás Eruripidésznél.

Krähling Edit: To d'eidenai ti deinon (Szophoklész, Thrakhiniai 459. sor).

Nemes Zoltán: Az attikai theatronok.

Domány Judit: Az irónia problémája és Menandrosz Düszkolosza.

Révészné Bartók Gertrúd: Az ókori dráma komplex tanítása a humán osztályban.

Hajdu Péter: Az arisztotelészi Poétika aktualitása.

Hegyi W. György: Az ostoba Menelaosz.

Csepregi Ildikó: Mítoszpárhuzamok Seneca drámáiban.

Ferenczi Attila: Seneca, Agamemnón.

Takács László: A pseudo-senecai Octavia.

A harmadik szekcióban (egyéb) a következő elóadásokat tartották meg:

Adamik Tamás: „Apophaszisz megalé” (Simon mágus).

Havas László: Volt-e a klasszikus antikvitásnak történelemfilozófiája.

Németh György: Szkülax, egy gemmavésnök és a politika.

Tegyey Imre: Kydónia.

Déri Balázs: „Gloriosa proelia”. Egy késő ókori keresztény himnusz elágazásai. 
Adamik Béla: Latin nyelvemlékek Konsztantinosz Porphürogennétosz De ceremoniis aulae Byzantinae c. múvében.

Pesthy Monika: Evagriosz Pontikosz levele Melainához.

Tar Ibolya: Calvus redivivus.

Borhy László: Ammianus Marcellinus és a késő római erődépítészet.

Forisek Péter: A nagy év az antik irodalomban.

Luft Ulrich: Aszklépiosz.

Grüll Tibor: „Munus Tiberium”.

Fábián Zoltán: A thébai magyar ásatások legújabb eredményei.

Kiss Magdolna és hallgatói: Origo Constantini Iordanes Getica.

Szabó Ádám: P. Aelius Antipater 1977-ben közölt feliratának kiegészítéséhez.

Horváth László: Hüpereidész, a démokolax.

Darab Ágnes: Az idősebb Plinius embereszménye.

Ornódi Zsuzsa: A középiskolai latintanítás helyzete: tanárképzés.

Simon Zoltán: Satietas mea gaudia vexat (a Carmina Einsiedliensia).

Szabó Edit: A pannoniai municipalis arisztokrácia kapcsolatrendszere.

Az Ókortudományi Társaság felolvasó ülésein 13 magyar előadó tartott előadást, ebből 5 a régészet, 1 a patrisztika, 1 a görög irodalom, 1 az egyiptológia, 1 a görög történelem, 2 a római irodalom, 1 a római történelem, 1 az egyházi zene témakörét érintette. A renkívüli előadók között 2 magyar is volt, akik a filozófia térgykörébe tartozó előadásokat tartottak.

A Debreceni Tagozat öt előadója közül 3 a római történelemmel, 1 vallástörténettel, 1 pedig nyelvészettel foglalkozott.

A Szegedi Tagozat 1 magyar elóadója a vallástörténet témaköréből tartott elóadást.

Az Ókortudományi Társaság budapesti és vidéki felolvasóülésen a magyar előadók összesen 21 elóadást tartottak az elmúlt évadban. Ebből 5 a régészettel, 1 a patrisztikával, 1 a görög irodalommal, 1 az egyiptológiával, 1 a görög történelemmel, 2 a római irodalommal, 4 a római történelemmel, 1 az egyházi zenével, 2 a vallástörténettel, 2 az antik filozófiával és 1 a nyelvészettel foglalkozott. Az előadásoknak ez a rendkívüli változatossága egyrészt a magyar ókortudomány sokrétúségét szemlélteti, másrészt kifejezésre juttatta azt az igazságot, hogy az ókortudomány több résztudomány összessége.

Megerősíti ezt a változatos képet a Kapitánffy István emlékének szentelt konferencia, amelyen 26 magyar tartott elóadást a görög történelem, a görög retorika, az antik múvészet, a görög tudománytörténet, a patrisztika, a római irodalom, a római történelem, a középkori irodalom és történelem, lexikográfia, bizantinológia, az ókori kelet és a nyelvészet témaköréból.

Ugyanilyen változatosságról tanúskodik a IV. Magyar Ókortudományi Konferencia, amelynek ugyan az antik színház és filozófia volt két fơ témáköre, azonban az egyéb szekció a többi tudományágat is szóhoz engedte jutni. Az egyéb szekció 20 elóadása igen változatos volt: görög irodalom, római irodalom, római történelem, régészet (epigráfia), mükenológia, vallástörténet, nyelvészet, patrisztika, a latintanítás, a továbbélés, a recepció kérdése.

E konferencia fontos eredményének tekinthetô, hogy az antik drámára és filozófiára irányította a figyelmet, és természetes, hogy e két témakörből hangzott el a legtöbb előadás. A harmadik helyet azonban az ókeresztény irodalommal (patrisztikával) kapcsolatos előadások, szám szerint tíz, szerezték meg. S ha ehhez hozzávesszük még az apokrif konferenciánk hat magyar előadását, akkor meg kell állapítanunk, hogy az ókeresztény irodalom előtérbe került a magyar ókortudományban. A konferencia legnagyobb eredményének mégis azt a tényt tarthatjuk, hogy az ókortudomány már-már szétesô, egymástól elszakadó területeit - az antik irodalmat, történelmet, filozófiát, patrisztikát, régészetet, múvészettörténetet és nyelvészetet — ismét közelebb hozta egymáshoz, s ezzel felhívta arra a figyelmet, hogy e tudományágak egymásra figyelve, egymás eredményeit felhasználva érhetnek el új eredményeket.

3. Az Ókortudományi Társaság fontos feladata az ókortudomány eredményeinek és az ókor irodalmi alkotásainak közzététele, illetve e közzététel támogatása. A magyar ókortudomány két reprezenta- 
tív folyóirata az Antik Tanulmányok és az Acta Antiqua. Az elóbbi magyar nyelven magyar olvasóközönségnek, az utóbbi idegen nyelven nemzetközi szinten ad számot a Magyarországon folyó ókortudományi kutatásokról. Ebben az akadémiai évben méltán illeti különös dicséret a két folyóirat felelős szerkesztôjét, Borzsák Istvánt és Ritoók Zsigmondot, mert mindkét folyóirat pontosan, időre megjelent, mégpedig megfelelő terjedelemben. A pontos, időre való megjelenést azért kell hangsúlyozni, mert a korábbi években gyakran késtek e jelentôs folyóirataink, ez évben viszont mindkettő́ből megjelent már az 1999-es szám, és a 2000. kötet anyaga is össze van állítva. Ugyanez elmondható a debreceni Ókortörténeti Tanszék és a debreceni Klasszika-filológiai Tanszék gondozásában készülő Ókortudományi Értesítőrôl és Acta Classicáról. A megfelelő terjedelem pedig azért érdemel említést, mert az anyagi nehézségek ellenére sem került sor azokra a terjedelmi korlátozásokra, amelyek pénz szúke miatt az Antik Tanulmányokat és az Acta Antiquát fenyegették.

Ami a magyar ókortudomány két élő sorozatát, az Apollo Könyvtárt és az Auctores Latinit illeti — mint ismeretes - átmeneti anyagi nehézségek miatt egy idôre mindkettő megszúnt, az előbbit azonban sikerült újraindítani. Az utóbbi években az Apollo Könyvtár sorozat szerkesztése és megjelentetése kissé vontatottan haladt: Maróti Egon „Delphoi és a Pythia sportversenyei” 1995-ben, Varga Edit „Napkorong a fej alatt” címú kötete 1998-ban, Hegyi Dolores „A görög Apollón-kultusz” címú munkája szintén 1998ban, Rimóczi-Hamar Márta „Horatius, Vergilius és Maecenas” kötete pedig 2000-ben jelent meg. Hogy a sorozat megjelenését gyorsítsuk, kísérletképpen átvittük az Argumentum Kiadóhoz. Itt jelent meg a sorozat 21. kötete (Maróti Egon „A delphoi Pythia sportversenyeinek győztesei”).

Már nem ilyen jók a kilátások az Auctores Latini tankönyvsorozat esetében. A sorozatból 24 kötet elkészült ugyan, azonban az elfogyott kötetek újranyomására a Nemzeti Tankönyvkiadó nem vagy csak nehezen vállalkozik. Pedig olyan auktorok esetében, akiket nagy óraszámban olvastatunk latin szakon — például Vergilius és Horatius - e kommentáros szövegkiadások hiánya komoly problémákat okoz. Mintegy két évvel ezelőtt a Tankönyvkiadó megjelentette Catullust harmadik kiadásban, 1000 példányban. Erre hivatkozva a minap felhívtam a Kiadó Egyetemi Szerkesztőségének főszerkesztőjét, aki arról tájékoztatott, hogy a két év alatt Catullus 3. kiadásából mintegy 250 példány fogyott el, és ilyen fogyásra lehetne számítani a Vergilius- és Horatius-kötetek esetében is, ami a mai könyvpiac igényeit nézve nem csekély. Ehhez azonban a Kiadónak biztosíték kell, azaz azok az Egyetemek, amelyeken latin szakos képzés folyik (a pesti, a debreceni, a szegedi, a pécsi és a Pázmány Péter Katolikus Egyetem), jelentsék igényeiket a Tankönyvkiadónak, vagyis hogy évente hány kötetet igényelnek Vergiliusból és Horatiusból. A Kiadó ugyanis csak abban az esetben adja ki újra ezeket a nagy szerzőket, ha biztosnak tekintheti az évi 100-150 példányos fogyást. Már tavalyi beszámolómban is felhívtam erre a figyelmet, az illetékes latintanszékek azonban nem jelentették igényeiket. Ez alkalommal ismételten kérem a latintanszékek vezetőit, hogy igényeiket most jelentsék be a Tankönyvkiadó Egyetemi Szerkesztôségének, mert úgy túnik, ez esetben a Kiadó most hajlandónak mutatkozik a Vergilius- és Horatius-kötetek újranyomására.

4. Az Ókortudományi Társaság — az Oktatási Minisztérium támogatásával — a 2000. évben is megrendezte országos tanulmányi versenyét. A milleniumra, illetve bimilleniumra tekintettel a verseny szervezóbizottsága elhatározta, hogy idén elsố alkalommal az országos verseny szervezeti keretein belül külön versenyt hirdet meg a latin nyelvet első éve tanuló legfiatalabb korosztály számára is. A szervezőbizottságot e döntésében több érv is motiválta. Egyrészt már régen felmerült az igény a latintanárok körében, hogy a legkisebbek valamilyen módon külön versenyezzenek, másrészt célszerúnek tûnt, hogy a különféle országos versenyek a latint tanulók összes korosztályát lefedjék, harmadrészt pedig tudatában vagyunk annak, hogy a tudományszakunk utánpótlásának kinevelésében alapvetô szerepet játszó középiskolai latinoktatás jelenlegi helyzetében versenyünknek komoly megtartó szerepe van.

A verseny sikeres megrendezéséért köszönetet mondok minden latintanárnak, mert napjainkban igen mostoha körülmények között végzik oktató munkájukat. Fáradozásaik értéke felbecsülhetetlen, mert amíg ők minden nehézséget vállalva tanítják a latin nyelvet, az ókori kultúrát és humanizmust, addig a tudományos utánpótlás is biztosítva lesz Magyarországon. De köszönet illeti azon tagtársainkat is, akik a 
versenyt szervezték és sikeresen lebonyolították, közöttük is Rimóczi Gáborné Hamar Mártát, Mayer Gyulát és Adamik Bélát.

5. Az Ókortudományi Társaság ez évben is jutalmazta a legjobb tudományos teljesítményeket.

A legjobb recenzióért járó Révay-díjat Hajdu Péternek ítélte oda a BUKSZ 1999/2. számában publikált könyvbírálatáért, melyet „Arisztotelész: Poétika és más költészettani írások” címú kötetrôl írt (Fordította Ritoók Zsigmond. A kötetet szerkesztette, és a jegyzeteket összeállította Bolonyai Bábor, PannonKlett, 1997). Hajdu Péter egyike azon keveseknek, akik mernek bírálatot írni elismert ókortudósok munkájáról. Ugyanakkor kritikája nem öncélú. Amikor szőrszálhasogatónak tû́nő részletességgel vitatja a fordítás egyes mondatait, akkor is az érdekli, hogyan lehetne az arisztotelészi elmélet lényegi összefüggéseit pontosabban közvetíteni. Átgondolt javaslatokat tesz olyan fordításelméleti problémák megoldására, mint amilyen például az, hogy elkülönítsük-e, s ha igen, miképpen az egyes kifejezések terminusértékú és nem terminusértékú használatát. Alaposan foglalkozik a fordítás és a kommentár viszonyával. A kommentár egyes pontjaival folytatott vitája egyéni felfogást sejtet Arisztotelész Poétikájáról és a görög drámáról.

A jelentôs új eredményeket felmutató tudományos monográfiáért járó Marót Károly-díjat Pesthy Monikának és Németh Györgynek ítélte oda az Ókortudományi Társaság vezetősége.

Pesthy Monika az újraéledő magyar patrológia fontos, nemzetközileg is elismert személyisége. „Órigenész, az exegéta” címú monográfiája 1996-ban jelent meg az MTA Judaisztikai Kutatócsoportjának kiadásában. Ebben a könyvében Órigenész exegetikai elméletét összeveti azzal a módszerrel, amelyet az egyházatya a Jeremiás-homiliákban követ. Arra az eredményre jut, hogy a homiliában a rejtett értelemnek több típusa különböztethető meg, mint ahányról a principiumokról írott múben olvashatunk. Érzékletes példákkal mutat rá, hogy Órigenész a Peri arkhónban kifejtett exegetikai elveket mindig az adott szövegösszeföggésnek, a múfajnak és a hallgatóságnak megfelelően alkalmazza, tehát ez az allegorikus módszer a gyakorlatban nemcsak a középkorban főként Órigenész nyomán kifejlesztett írásmagyarázó methódusnál, hanem magánál az órigenészi elméletnél is gazdagabb, nem is beszélve a modern Órigenész-kutatók sémáiról. Pesthy Monika kutatásait jól kiegészítik tartalmi és formai szempontból egyaránt igényes Órigenész-fordításai: Kommentár az Énekek énekéhez (Atlantisz 1993) és A principiumokról, IV. könyv 1-3 (Hermeneutikai Kutatóközpont, Budapest 1998). Mindkét kötetet tudományos előszó vezeti be, s a magyar szöveg megértését gazdag kommentár segíti.

Németh Györgynek az elmúlt évben „A poliszok világa” (Korona Kiadó, Budapest, 1999) címmel megjelent könyve évek óta folytatott kutatásait foglalja össze és fejleszti tovább. A szerzó nemzetközileg is figyelemre méltó számítógépes adatbázist hozott létre a görög városállamokra vonatkozólag, mely alapul szolgált eredeti megközelítésú kutatásaihoz. Múve alapgondolata az, hogy számos jól ismert társadalmi jelenséget és változást, mind a magánélet szférájában, mind a közösség életében, a viszonylagos túlnépesedés problémája idézett eló. Németh György éppoly otthonosan mozog a papirologia és az epigráfia területén, mint az írott források hagyományosabb világában. Kutatásai alapos régészeti és múvészettörténeti ismeretekre támaszkodnak és alkalmazzák a történettudományok legújabb módszereit is.

A legeredményesebb latintanár számára kiírt Faludi Szilárd-díat az Ókortudományi Társaság vezetősége ez évben Benőné Hegyi Amáliának adományozta több évtizedes oktatói-nevelői tevékenységéért, amelyet mind a tanórán, mind azon kívül a drámai bemutatókon nagy sikerrel folytatott. Külön köszönet illeti a tanári továbbképzések érdekében végzett áldozatos és eredményes szervezőmunkáját.

6. Az Ókortudományi Társaság tényleges tagjainak a száma jelenleg 408 fő. A tényleges tagon azt értjük, aki tagdíjbefizetéssel és a rendezvényeinken való megjelenéssel aktívan részt vesz társaságunk életében. E tagoknak rendszeresen küldünk meghívókat rendezvényeinkre. Az Ókortudományi Társaság évi tagdíja jelenleg diákoknak 500, mindenki másnak 1000 forint. Itt és most felhívom tagtársaink szíves figyelmét a tagdíjbefizetések időszerúségére, lévén hogy a befizetési csekkeket nemrég küldtük ki. Kérem továbbá kedves tagtársainkat, hogy a csekk közleményrovatában tüntessék fel, hogy milyen tudományszak 
iránt érdeklődnek (például római irodalom, patrisztika, filozófia stb), hogy rendkívüli előadások esetében a téma iránt érdeklődőknek küldhessünk meghívót.

Sajnos, mint általában minden évben, ez évben sem kímélte a halál társaságunkat. Nemrég távozott körünkből Csonka Ferenc tanár úr, aki a pozsonyi, majd a budapesti egyemen tanult, és szerzett diplomát magyar-latin szakon. Hosszú évekig tanította eredményesen a latin nyelvet gimnáziumban, majd 1972-tôl az MTA Irodalomtudományi Intézetének külső munkatársaként pontos és kitúnô múfordításokat készített Bocatius és Erasmus múveirơl, továbbá megbízható kiadásban adta közre Bocatius összes múveit Johannes Bocatius, Opera quae exstant omnia címen, három nagy kötetben. Tanárként szigorú következetességéről, kutatóként fanyar humoráról és filológiai precizitásáról vált ismertté. Emlékét kegyelettel őrizzük.

Végezetül kedves kötelességemnek teszek eleget, amikor köszönetet mondok a tisztikar meg a választmány tagjainak és mindazoknak, akik Társaságunk múködését az elmúlt év folyamán anyagilag és szellemileg támogatták.

ADAMIK TAMÁS 